\title{
Why do Hurdle Rates Differ from the Cost of Funds?
}

\author{
Ciaran Driver " \\ Paul Temple ${ }^{+}$ \\ I Tanaka Business School, Imperial College London, U.K \\ + Department of Economics, University of Surrey, UK
}

\begin{abstract}
Analysing a sample of business units from the PIMS data bank of North American companies we are able to extract data on investment hurdle rates, thus accessing a variable that is rarely observable. The text-book story maintains that firms should invest only if the return exceeds the cost of funds. Several theories however, explain the use of investment hurdle rates that differ from discount rates. We find that hurdle rates are frequently below and also frequently above matched data on discount rates. In a statistical analysis we find that this behaviour can be explained by a combination of agency theory and real options theory. We take this as important evidence that a full explanation of capital investment cannot be accomplished without a consideration of behavioural and strategic influences.
\end{abstract}

JEL codes:

G3, L2, L6, E22

Keywords:

INVESTMENT HURDLE RATE/ MULTINOMIAL LOGIT/ PIMS DATABASE/ AGENCY/STRATEGY/ REAL OPTIONS 


\section{Introduction}

"Increasingly, companies are becoming polarized into two camps: those who consider shareholder value the key to managing the company and those who put their faith in gaining competitive advantage. At companies across the United States there is an intense struggle taking place between those who formulate business strategy and those who seek to value it"

Alfred Rappaport, Harvard Business Review, May-June 1992

The dichotomy identified in Rappaport's observation reflected a contemporary debate as to whether underinvestment in US industry was fuelled by an excessive use of formal methods of investment appraisal. Such methods were said to result in companies underestimating the wider strategic benefits of investment so that projects had to be justified to company boards by "faith alone" (Kaplan 1986). Across countries too, differences in financial institutions between AngloUS and German-Japanese varieties of capitalism were argued to map onto corporate time horizons and to explain contrasting investment rates (National Research Council 1994). ${ }^{1}$

By contrast, others cautioned that lax controls on investment spending were allowing management too much autonomy from Board control. By this account, excessive investment was resulting in an overhang of excess capacity that could profitably be eliminated by tighter monitoring, incentive alignment, or devices such as higher leverage rates which, by reducing free cash flow, would limit the scope of individual managers to pursue rent-seeking activities (Jensen 1986, 1993)

The subsequent development and popularization of Real Options theory (Dixit and Pindyck 1994) provided a new set of tools for the examination of the issues, providing a justification for hurdle rates lying either below or above the cost of capital. In cases where investment created new knowledge or because the investment created a follow-on option (Brealey and Myers 2003;

\footnotetext{
${ }^{1}$ More recently this idea has been pursued in Allen and Gale (2000) and Holmstrom and Kaplan (2001)
} 
Schwartz and Trigeorgis 2001), we may observe hurdle rates below the cost of capital. At the same time Real Options theory also provided a justification for hurdle rates higher than the cost of capital in the context of irreversible investment under uncertainty. An illustrative case developed by Dixit and Pindyck results in a hurdle rate twice the discount rate; Wambach (2000) computes a premium of about $5 \%$ for a range of typical investments, while several other authors have found a premium that depends on industrial characteristics (Ghosal and Loungani 2000, Driver et al 2006).

In this paper we aim to establish whether the heterogeneity noted by Rappaport finds support in data on investment hurdle rates used in the private sector. If, as suggested, companies are polarised into shareholder oriented businesses (strong financial discipline) and those with managerial autonomy (lax financial discipline), we should expect to see this reflected in investment appraisal and specifically in the 'wedge' reported in our data between discount rates and hurdle rates. An important question is then whether this heterogeneity, if it occurs, can be explained by Real Options or other theoretical arguments. In what follows we present an analysis of hurdle rates using the PIMS (Profit Impact of Marketing Strategy) dataset of large industrial firms, mostly US based. We find that there is substantial evidence of heterogeneity in the manner in which companies appraise investment opportunities and that the differences across companies can be explained to some extent by established theories.

There have been surprisingly few direct studies of hurdle rates in capital budgeting, despite the wealth of theorizing on the topic. One reason for this neglect may be that hurdle rates are generally unrecorded and have to be found by surveys of company managers, so that consistent observation over time is difficult and reported studies are rare. One exception was a survey (of the Fortune 1000 companies) which used a set of reported hurdle rates in manufacturing industry for a particular year and which attempted to explain the considerable variation across 
the sample (Poterba and Summers 1995). ${ }^{2}$ However, despite entering a large range of financial and structural variables the authors failed to obtain any results that explained the diversity in hurdle rates and that accorded with prior theory. The one partial exception was that the current ratio (a possible proxy for free cash flow) was found - in a bi-variate regression - to be correlated with higher hurdle rates. ${ }^{3}$ The authors report the "striking conclusion...that none of the traditional financial variables that might proxy for risk, like the firm's stock market Beta, correlates with hurdle rates" (p.47). But if risk is not the major determinant of differences in hurdle rates, what is? As noted above, explanations for the observation of hurdle rates higher than the cost of capital is a real-options irreversibility premium (Jagannathan and Meier 2002). Hurdle rates lower than the cost of capital may be explained, as noted above either by lax control and a desire for empire building, or alternatively, by strategic use of follow-on options.

In this paper we use a range of variables to discriminate between the cases where the hurdle rate of a business unit is above or below its discount rate. Section 2 discusses the theoretical background and establishes some hypotheses for the empirical analysis. Section 3 describes the nature of the dataset we are using. We then describe the testing framework in section 4 , with results presented in Section 5.

\section{Why do hurdle rates differ from discount rates?}

In the standard literature on economics and finance, capital investment is pushed to the point where net marginal returns just equal the cost of funds. The presence or not of a premium

\footnotetext{
${ }^{2}$ Most companies in the sample appeared to use a real hurdle rate much higher than the real cost of capital. Indeed, typically, the hurdle rate was more than 3 percentage points above the real cost of equity but it was both much higher for some companies and it was negative for a substantial proportion - about a quarter of the total.

${ }^{3}$ A further bi-variate regression suggested that managers with financial backgrounds may be more inclined towards higher hurdle rates though the direction of causation here is somewhat unclear.
} 
payment for external finance does not alter that condition, although a hard financial constraint might imply that the return on the marginal project return exceeds the notional cost of funds. ${ }^{4}$ Usually, however, and especially for large firms that are representative of our sample, financial constraints are not hard and relate instead to the terms on which finance is available. In that situation, any gap that opens up between the marginal return and the cost of funds needs to be explained as a choice variable for the firm itself. This shifts the focus to the literature on possible overinvestment or underinvestment by firms. The latter relates to cases where target marginal returns (the hurdle rate) fall below the cost of funds and the former deals with the case where a reluctance to invest results in a hurdle rate higher than the cost of funds.

It has not been easy to test the relative incidence of over or under-investment, partly because of the difficulties in establishing counterfactuals and partly because behaviour may be contextspecific e.g. financialisation may have increased the pressure on firms to rein in investment (Driver and Shepherd 2005). Aggarwal and Samwick (2006). interpret a positive co-movement of investment and performance in response to stronger incentives as evidence against overinvestment. While this is consistent with much of the literature, it seems likely that both behaviours co-exist (Stein 2003). Although it is possible to make heroic attempts to nest various theories of over and under-investment (see Hennessy and Levy 2002), the results are then very dependent on the specification chosen for managerial incentives and compensation. ${ }^{5}$

Historically, overinvestment has had the largest share of attention. An important aspect of agency theory is the 'empire-building hypothesis' where managers or owner-managers pursue size or growth as a distinct objective (Baumol 1958; Marris 1964). Discretionary behaviour by

\footnotetext{
${ }^{4}$ For a review of financial constraint on investment see Hubbard (1998) and Stein (2003). The distortion introduced by financial constraint is not, however, clear-cut because risk-loving behaviour may emerge under financial distress (Opler and Titman 1994).

${ }^{5}$ Indeeed, this is the source of the conflicting claims in respect of the importance of empire building in Aggarwal and Samwick (2006) and Hennessy and Levy (2002).
} 
management (in situations of both weak corporate governance and product market discipline) has been formalized in the literature as an optimal trade-off between the utility attached to growth and the risks of takeover (Odagiri 1981). In this model, managers derive utility from job security which is thus the source of an agency problem. If $v^{*}$ is the value of the firm under profit maximisation (where the marginal product of capital is equal to the discount rate), actual firm value $v$ can be written as a function of the level of investment and of the permanent free cash flow ( $F$ ) available to the firm, discounted at some suitable rate $r$. The discrepancy between maximal and actual value is then $\partial v=v^{*}-(F-I) / r$ The probability of a take-over can now be written as $p(\partial v)$ with $p^{\prime}(\partial v)>0$. Since managers also derive empire benefits from growth, they have to trade that off against the risk to job security from non-profit maximizing behaviour and that may be captured by a utility function $U=U[g(I), p(\partial v)]$. Maximising $U$ with respect to $I$ yields a first order condition that ensures, under fairly unrestrictive conditions, that the marginal product of capital for the firm lies below the discount rate, indicating managerial caution or constraint (Kathuria and Mueller 1995).

Underinvestment can also be explained by agency theories e.g. theories that predict managerial "shirking", short-termism, or unwillingness to take risks. A parallel view characterizes underinvestment as a performance consequence of business school pedagogy, particularly in respect of formal investment appraisal methods such as NPV, with the accounting and finance function within firms privileged over strategy and operational management (Hayes and Garvin 1982; Adler 2006). To some extent, real options theory can then be seen as a way for strategists to defend investments that would otherwise fail on strict NPV terms. Thus, for example, if a project has an expected negative NPV but nevertheless offers the prospect of subsequently 
entering a new market which may be highly profitable, it could be justified on real options grounds. This is the case even if the second project as of the date of commencement of the first seems just as likely to lose money as the first one. The key element in justifying the first investment is that it offers the opportunity but not the requirement of participating in the second i.e. it offers the upside potential without the downside risks. ${ }^{6}$ These so-called "follow-on" investments may be particularly important in cases of new markets and new product innovations where there are clear first mover advantages. In recognition of this, lower hurdle rates may be allocated to such lines of business.

Somewhat paradoxically, however, while justifying positive investment when expected returns are negative, real options theory can also justify delaying investment when expected returns are positive. Indeed this is the standard case explained in most elementary treatments of real options where information is gained by delay and where delay is possible because the option (e.g. a patent or undeveloped land) will not be eroded by waiting. In these circumstances it makes sense to judge the moment to invest (exercise the option) as that which balances the cost of maintaining the option against the dangers of premature commitment to an irreversible outcome. Firms face a 'zone of inaction' in respect of the marginal value of capital, where it is optimal to keep the capital stock constant even if it differs from its frictionless optimal value. ${ }^{7}$

Here the irreversibility premium arises from the modification to the equilibrium condition for capital adjustment with marginal cost of adjustment $\mathrm{C}_{\mathrm{l}}$, which includes the purchase and installation price, as well as true adjustment costs. A perturbation argument ensures that the firm is indifferent between an increase in capital in by one unit in period $t$ and a decrease in period $t+1$ with subsequent periods unaffected. Of course present adjustment costs have to reflect

\footnotetext{
${ }^{6}$ The literature shows that in a range of circumstances, such as when abandonment is possible or where there are delivery lags, it may be sensible for the firm to initiate projects with negative expected return (Ghemawat 1991, Dixit and Pindyck 1994, Bar-Ilen and Strange 1996, Miller and Folta 2002, Schwartz and Trigeorgis 2001).

${ }^{7}$ This zone of inaction may be due to non-convex costs of adjustment (Abel and Eberly 1994) or a combination of irreversibility and uncertainty (Dixit and Pindyck 1994; Chirinko and Schaller 2002; Folta et al 2005).
} 
interest and depreciation, but that is balanced by the marginal return on capital $\left(\pi_{K}\right)$. We thus obtain (Romer 2000; Chirinko and Schaller 2001)

$(1+r+\delta) C_{I, t}=\pi_{K, t}+E\left[C_{I, t+1}\right]$

The expectation of $C_{\mid}$for the next period however must take account of the irreversibility of investment. This is because firms cannot adjust smoothly in the presence of either fixed adjustment costs of uncertainty with irreversible. If the firm anticipates disinvestment at the distress price, it would imply a hurdle rate above the cost of capital. ${ }^{8}$

These opposing effects on investment from the real options literature have spawned an immense set of applied studies most of which focus on a single type of option. Hybrid theories of real options are of course possible, as when a firm is simultaneously faced with deciding on projects with multiple conflicting characteristics. For example, a project may be irreversible and at the same time convey an option to expand. In these circumstances it is the balance between the option effects that is important (Folta and O Brien 2004; Kulatilaka and Perotti 1998; Driver et al 2006).

\section{Formulating Hypotheses}

Distortions to standard rules of investment appraisal may arise due to the agency-inspired theories of empire building and managerial shirking or, via the ambiguous effects of real options. We combine the various elements of theory reviewed above to derive testable hypothesis. As there may be hybrid influences, we try to identify circumstances where it is most likely that the

\footnotetext{
${ }^{8}$ Rules of thumb for hurdle rates in excess of the discount rate are derived from real options theory in McDonald (2000).
} 
critical marginal return set by managers (the hurdle rate) is above or below the cost of funds (the discount rate). ${ }^{9}$ Our discussion to date suggests three main hypotheses:

H1: There will be a higher likelihood of observing hurdle rates below discount rates when managers have discretionary power

However, it is important to note that the existence of discretionary power need not imply "overinvestment". To consider this we need to test:

H2: There will be a higher likelihood of observing hurdle rates below discount rates when managers experience strategic incentives.

Note that if $\mathrm{H} 1$ is true but not $\mathrm{H} 2$, then this indicates Jensen type "over-investment". If both are true, the low hurdle rate may be explained by managers pursuing strategic objectives.

For the third hypothesis we consider reasons for lower investment than would be warranted by a simple application of NPV:

H3: There will be a higher likelihood of observing hurdle rates above discount rates when managers are either shirking or, are profit-maximising but subject to an irreversibility constraint, implying the importance of idiosyncratic risk and irreversibility.

\footnotetext{
${ }^{9}$ Our set of theories is not exhaustive and is chosen to correspond with our unique set of data. Other complex influences have been noted in the literature as where capital rationing is used to substitute for auditing and monitoring (Antle and Eppen 1985) or to prevent over-investment caused by managers signalling their performance (Holmstrom and Costa 1986). Related literature investigates how variables such as audit costs or the specific nature of empire benefits might influence overinvestment (Harris and Raviv 1996; Baldenius 2003), how agency problems and real options interact (Grenadier and Wang 2004, Friedl 2005), or how rationing may elicit private information from managers (Qi Chen and Wen Jiang 2004). Complications also arise when options are held under rivalrous conditions (Schwartz and Trigeorgis 2001). Furthermore non-unique equilibrium outcomes are obtained when entry is rivalrous and where real options effects may interact with the distribution of firms' costs (Pawlina and Kort 2006). Empirical testing of these models would require additional matched data.
} 
One point that needs clarification is the extent to which the hurdle rate is set by the division (or line of business) or is set centrally and imposed on the division. Previous work on capital budgeting and allocation has shown these to be interactive processes between divisions and headquarters ..."division managers are granted some discretion over capital expenditures and they share their special knowledge with headquarters" (Taggart, 1987 p.188). It is possible that the location of the decision on hurdle rates has little consequence for the analysis in this paper in that any set of influences (agency or real options) that would be present for division managers may well also be reflected at headquarters. But even if that is not the case, the "hurdle" rates recorded in our data i.e. the required rate of return the divisional managers use in planning new investment, are unlikely to be unilaterally dictated by headquarters. Large corporations find it difficult to micromanage their divisions so there is probably a degree of strategic autonomy in relation to investment planning. Wulf (2002) in an extensive empirical appraisal notes that "...there is rent seeking behaviour by division managers ...they have an incentive to engage in influence activities and distort subjective information about investment opportunities" (p.2) There is thus leeway for division managers to pursue distinct interests as when, for example opportunities for promotion are increased through growth strategies (Odagiri 1992).

We now briefly describe the data set used to test the three hypotheses above $\mathrm{H} 1-\mathrm{H} 3$.

\section{The PIMS Dataset}

The data source used in this paper is the PIMS (Profit Impact of Marketing Strategy) crosssectional database of large firms, established in 1972 at Harvard University. The reporting base 
consists of over 3000 business units mainly based in the US - representing 450 companies and which are considered to be selling a 'distinct set of products to a well-defined set of customers', therefore corresponding to narrow market segments which are at least as fine as the four-digit Standard Industrial Classification (SIC).The PIMS program is described in detail in Buzzell and Gale (1987). The data have been extensively used in applied research (e.g. Clark and Griliches 1984, Ghemawat and Caves 1986, Caves and Ghemawat 1992). The data are prepared by managers of each business unit under detailed guidance from PIMS consultants. The sample period for the cross section covers 1972 to 1992 with the data being collected in five-year blocks. ${ }^{10}$ Firms subscribe to PIMS as a way of benchmarking performance in different businesses; a digest of the results in ratio form is returned to firms to allow them to compare indicators such as R\&D intensity, capacity utilization, or profitability. Data that are not in ratio form are disguised by being scaled using a constant term specific to each business unit. Of course these data have all the virtues and shortcomings of any survey-based sample; they are direct and consistent in that all variables are collected from the same source. On the other hand, they are only as reliable as the reporting managers choose to be. However, when used in applied work, the data have underpinned a number of interesting analyses (Roberts 2003, Buzzell 2004). Furthermore, as the ensuing discussion on the interpretation of hurdle rates and discount rates makes clear, considerable effort was expended in making the questions clear to the respondents.

Most of the variables used in the following analysis are reasonably self-explanatory and are listed and annotated in the Data Appendix. However, we give here the actual PIMS definitions of the terms 'hurdle rate' and 'discount rate', for which the specific instructions relating to their reporting were:

\footnotetext{
${ }^{10}$ If there are multiple blocks for any business unit, the latest block only is recorded in the sample.
} 
Discount rate: "The discount rate is used in computing the present value of a stream of future income or cash flow. You can think of it also as your opportunity cost of capital (i.e. your company's cost of debt and equity)"

Capital Charge Rate: "In calculating discounted net income what capital-charge rate should be applied to any additional investment that would be required to pursue the various strategy alternatives available to your business? The capital charge rate can be used to simulate financing costs for new investment"

PIMS tells its respondents that "the discount rate indicates the degree to which current income or cash flow is more valuable than future income or cash flow", i.e. it is a conventionally defined weighted average cost of capital (WACC). Similarly, the capital charge rate "indicates the degree to which your business should be encouraged to seek (or be penalized for seeking) additional investment funds". It is clear therefore that the capital charge rate is indeed a "hurdle rate"11

Key descriptive statistics of our dataset are reported in the Data Appendix below. In our data 2382 business units reported both hurdle rates (our variable identifier below is $H R$ ) and discount rates (DR). Of these 1425 over half reported that they used hurdle rates that were equal to their discount rates, though we interpret this to be "approximately equal" due to the preponderance of rates given to the nearest $5 \%$ which is probably due to the guidance given by PIMS consultants . We refer to these units as the 'EQUAL' sample). Of the remaining units, 505 units reported using hurdle rates less than the discount rate (the 'BELOW sample), with the remaining 452 units reporting hurdle rates above the discount rate (the 'ABOVE sample).

\footnotetext{
${ }^{11}$ These interpretations of the discount rate and hurdle rate were confirmed by PIMS in private correspondence. Note that we are only using the representaitve "hurdle rate" recorded in the survey. In defence of our approach, the analysis is done at the line of business level where there will be less scope for multiple rates. Furthermore, the recorded rate is representative, given that it is identified by managers in discussion with PIMS consultants. Hurdle rates may also change over time but we have chosen a single time block (the latest available) for each line of business and controlled for the time period by using the discount rate as a control (see text for estimation methods).
} 


\section{Empirical Testing}

Under hypotheses $\mathrm{H} 1$ and $\mathrm{H} 2$, described in section 2, the case where the hurdle rate is lower than the discount rate (the BELOW sample) is predicted by the opportunity to engage in empire building and by the existence of real follow-on options. By contrast, under $\mathrm{H} 3$, the $A B O V E$ sample, is predicted by a reluctance to invest - perhaps due to managerial shirking - or a combination of risk and irreversibility (deferment options). For emphasis we set this out below:

\begin{tabular}{|c|c|c|c|c|}
\hline $\begin{array}{l}\text { SAMPLE } \\
\text { OBSERVED }\end{array}$ & $\begin{array}{l}\text { VARIABLE } \\
\text { IDENTIFIER }\end{array}$ & IMPLICATION & HYPOTHESIS & $\begin{array}{l}\text { CONDITIONING } \\
\text { VARIABLES }\end{array}$ \\
\hline $\begin{array}{l}\text { Hurdle }<\text { Discount } \\
\text { (HR) (DR) }\end{array}$ & BELOW & $\begin{array}{l}\text { Managerial/ } \\
\text { Strategic Behavior }\end{array}$ & $\mathrm{H} 1 / \mathrm{H} 2$ & $\begin{array}{l}\text { Opportunity } r \text { for } \\
\text { Empire } \\
\text { (OEB)/ } \\
\text { OEB and } \\
\text { Existence of follow- } \\
\text { on options }\end{array}$ \\
\hline $\begin{array}{l}\text { Hurdle>Discount } \\
(\mathrm{HR}) \quad(\mathrm{DR})\end{array}$ & ABOVE & $\begin{array}{l}\text { Profit Maximizing } \\
\text { with Irreversibility }\end{array}$ & H3 & $\begin{array}{l}\text { Risk and } \\
\text { Irreversibility } \\
\text { implying deferment } \\
\text { options; Shirking }\end{array}$ \\
\hline
\end{tabular}

\section{Variables that help identify the BELOW group}

Not all firms are in a position to maintain (long-run) investments at hurdle rates lower than the 
discount rate. The corporate governance literature suggests that, in the presence of asymmetric information, a necessary condition for such opportunity is the existence of free cash flow (Jensen 1986; Henderson and Cool 2003). Managerial autonomy may also be constrained in ways other than the availability of internal finance. A number of authors have noted that product market competition is important in disciplining managers. In that respect, competition in product markets (from end-users and competitors) substitutes for direct monitoring by shareholders or their representatives and makes the latter less costly (Allen and Gale 2000; Gillan 2006). ${ }^{12}$ Proxies for limitation on managerial discretion available to us from the PIMS dataset and employed in this study were as follows (further information on variables can be found in the Data Appendix):

- Liquidity: a ranking of business units according to the ratio of cash-flow to sales [ $L I Q$ ]

- Lack of market discipline expressed as the \% of sales channeled to distribution facility [SDF]

- Inverse lack of market discipline expressed as the \% of sales channeled to retailer [SR]

- Existence of a barrier to entry expressed as "capacity quantum" or degree of lumpy capital [LUMP]

- Existence of a barrier to entry expressed as capital intensity, the ratio of fixed capital to sales $[K S]$

\section{Variables that help identify the ABOVE group}

\section{Real Follow-On Options}

The incentive to pursue growth should be related to the strategic value of investments. Here we use a variable recording the percentage of sales accounted for by new products so as to capture the innovativeness of the business unit and therefore the value of follow-on options. This

\footnotetext{
${ }^{12}$ A number of subtle effects may mediate the effect of competition on performance. For example competition may enhance the ease with which managerial performance can be compared (Nickell 1995)
} 
variable may be preferable to variables such as $R \& D$ to sales ratio where the intensity is known to depend on sector characteristics that favour certain types of technical innovativeness.

\section{Opportunities for Managerial Shirking}

The opportunity to shirk will be influenced by some of the same variables that influence empire building in the BELOW group. We also include here other indicators of the competitive environment which may limit the opportunity to shirk. Given that major entry generally disrupts the quiet life scenario, companies have to choose between an accommodating response which results in ceding market share or an aggressive response to maintain position. Either response is possible depending on the nature of the strategic game, but much of the literature suggests that new entry stimulates incumbents to increase investment that firms have been holding back. ${ }^{13}$ This implies that previous major entry will predict against current membership of the ABOVE group.

Accordingly, the specific extra variables included are:

- $\%$ sales from new products [SNP]

- major entry $[E N T]$

\section{Risk factors}

Risk should already be accounted for as part of the discount rate in so far as it reflects the equity risk premium but total risk may also be important (Stulz 1999). Survey research shows that demand (sales) risk is of primary concern to firm managers (Driver and Whelan 2001). Hence

\footnotetext{
${ }^{13}$ See Geroski (1995) for a review and especially p.1431 Note that major new entry is independent of the barriers to entry variables discussed earlier in that new entry relates to the entry in the "past three years".
} 
we include a measure of the industry sales volatility provided in PIMS:

- Industry instability [INSTAB]

Statistical summaries of these variables for each of the outcomes and the total sample are reported in the Appendix.

Clearly we could encounter hybrid cases where the variables indicating membership of the $B E L O W$ and $A B O V E$ groups are jointly operative. However, as long as this is borne in mind, the dichotomy remains useful as a potential source of heterogeneity across firms. In the empirical analysis that follows, we use a multinomial logit analysis to differentiate the between the ABOVE, EQUAL and BELOW outcomes, conditioning on the opportunity, and on the incentive, to act strategically, as well as on measures of risk and irreversibility.

\section{Estimation and Results}

This section reports experiments with discrete choice models in which we consider all three outcomes in the observed relationship between the hurdle rate and the discount rate BELOW, EQUAL, or ABOVE - as being conditioned on our measures of opportunity and incentive as discussed in the last section. ${ }^{14}$ Moreover, while there is an ordering of outcomes suggests that the ordered logit estimator may be appropriate, our earlier discussion also suggests that rather different factors may explain membership of the different groups and that

\footnotetext{
${ }^{14}$ As noted earlier while in theory we have continuous data, the tendency for answers to be to the nearest $5 \%$ adds another reason for our chosen estimation method.
} 
some variables may therefore have an ambiguous impact, making the use of an ordered logit less appropriate than a multinomial logit. Specifically variables that predict membership of the $B E L O W$ group may not be hypothesized to predict against membership of the ABOVE group. This is quite likely in our sample where a variable may be proxying for different influences on these groups, as discussed later in regard to the results for the product innovation variable $(S N P)$. Thus, we use the following multinomial logit model:

$$
\begin{aligned}
\operatorname{Pr}\left(Y_{i}=\jmath\right. & =\exp \left(\boldsymbol{X}_{i} \boldsymbol{\beta}_{j}\right) /\left(\Sigma_{\mathrm{j}}\left(\exp \left(\boldsymbol{X}_{i} \boldsymbol{\beta}_{j}\right)\right)\right. \\
j & =1,2,3(B E L O W, \text { EQUAL, ABOVE }) \\
i & =1, \ldots, N
\end{aligned}
$$

Where $\boldsymbol{x}_{i}=\left(L I Q_{i}, S D F_{i}, S R_{i}, L U M P_{i}, K S_{i}, S N P_{i}, E N T_{i}, I N S T A B_{i}\right)$

and $\boldsymbol{\beta}_{j}$ is a set of constants for each of the three outcomes.

The key feature of the multinomial logit estimator for our purposes is that it allows the estimated set of coefficients $\boldsymbol{\beta}$ to vary between outcomes. However as the probabilities sum to one, identification of $\boldsymbol{\beta}_{j}$ requires that one of the sets of coefficients arbitrarily be set to zero. In our reported results in Table 1, 'EQUAL' is used as the comparator group (i.e. $\boldsymbol{\beta}_{2}=\mathbf{0}$ ).

\section{\{TABLE 1 ABOUT HERE $\}$}

Table 1 reports the results of four experiments. The first result set (1.1) records coefficient estimates for the base line specification which includes each of the variables discussed in the last section. The second set of estimates (1.2) includes an additional regressor (LIQSQ) - the square of the cash-flow term $(L I Q)$ to allow for a possible non-linear effect of cash-flow. The third 
result set (1.3) omits one of the regressors - our measure of risk (INSTAB) - the inclusion of which affects the sample size, while the fourth (1.4) restricts the sample to manufacturing.

All the variables discussed earlier are found to be significant or very significant in distinguishing the BELOW from the EQUAL group and thus hypotheses $\mathrm{H} 1$ and $\mathrm{H} 2$ are both supported. The results for the $A B O V E$ group show that the variables for managerial motivation contribute significantly to discriminating between this group and the EQUAL group. Comparing 1.1 and 1.2, we found that the inclusion of the cash-flow squared term in the latter (LIQSQ) generally improved the diagnostics but had little impact on the reported signs of the other variables. Result set 1.2 therefore provides our preferred set of estimates in the discussion below. The final experiments - 1.3 and 1.4 - provide robustness checks by changing the sample. As our measure of risk is not recorded for a substantial number of business units, 1.3 increases the sample size (from 1514 to 2263) by dropping our risk measure (INSTAB). Most of the coefficients remain stable in terms of sign and significance, although our market share indicator $(M S R)$, which may be proxying for a price elasticity effect on expansion, is now insignificant for both groups. In the final experiment (1.4), the sample is restricted to the units known to be in manufacturing industry. The results here are similar to 1.2 though the sample size has been reduced by a third. It is, perhaps, of interest that the effect of the risk variable INSTAB is greater in magnitude and significance for this set of results, particularly for the BELOW group, in line with expectation that sunk cost might be more important in this sector. ${ }^{15}$ Further results for experiments 1.1 and 1.2 are reported in Table A3 of the Appendix. They also suggest that 1.2 should be the preferred result, and that neither the Hausman or Small-Hsiao tests that the estimated probabilities between outcomes are independent of the omitted alternative can be rejected.

\footnotetext{
${ }^{15}$ Manufacturing business units are also likely to be larger than service ones, so the results are also in line with findings in Ghosal and Loungani (2000).
} 
In order to comment on the results in detail, the marginal probabilities need to be computed. These have been derived from our preferred result set 1.2 and are reported in Table 2 in the form of the estimated change in probability for each outcome arising from a unit change for the variable in question. The marginal probabilities are evaluated at the means of the variables, except in the case of the dummy variable representing major entry, which was evaluated at zero (i.e. with no major entry).

\section{\{TABLE 2 ABOUT HERE\}}

The results in Table 2 provide very strong evidence for the importance of the opportunity set in distinguishing the BELOW outcome from the EQUAL outcome. Importantly, cash flow (LIQ) appears to facilitate managerial or strategic behavior. Although the cash flow term is non-linear, the overall impact of an increase in cash-flow is nonetheless positive in predicting membership of the BELOW group. Other opportunity set variables include indicators of market discipline, of which the most important influences are the variables representing customer power. For the $B E L O W$ outcome, both the \% of sales channeled to a retailer $(S R)$ and the \% channeled to own distribution (SDF) facilities are significant and signed in accordance with expectation. The other opportunity variables representing barriers to entry also predict membership of the BELOW group, all with the anticipated sign and significant (at $5 \%$ for the capital-sales ratio - KS - and at the $1 \%$ level for capacity quantum - LUMP). Moreover, although the impact of cash flow is predominant, the estimated impacts of at least some of the other variables are also reasonably large. This can be seen from Figure 1, where the marginal probability of each variable is multiplied by its respective standard deviation.

\{FIGURE 1 ABOUT HERE\} 
Figure 2 plots the marginal probabilities of the different outcomes of a one percentage point improvement in cash-flow at different levels of cash-flow. The estimated impact of a movement to a higher percentile in the cash-flow ranking is to increase the probability of a BELOW outcome by slightly less than 0.006 for the poorest units in terms of cash-flow (at the $10^{\text {th }}$ percentile). This probability rises to about 0.01 at its peak around the $40-50^{\text {th }}$ percentile before trailing off to below 0.006 for the cash rich units at the $90^{\text {th }}$ percentile.

\section{\{FIGURE 2 ABOUT HERE\}}

Turning now to the set of variables representing strategic incentives, support can be found in Table 2 for this as set out under Hypothesis 2. A noteworthy feature of the results - and which lends support to our choices of the multinomial logit estimator - is that the sign of the new product variable $(S N P)$ is positive and significant for both the BELOW and the ABOVE groups suggesting that product innovation encourages strategic investment for some business units and discourages it for others. This heterogeneity, which the multinomial logit technique is designed to capture, probably reflects different approaches by different managers as suggested in our introductory comments. On the one hand, new product intensity may confer an option to expand that justifies strategic loss-making pilot investments (Folta and O'Brien 2003), and therefore membership of the BELOW group. On the other hand, new product intensity is also likely to be associated with divisions that attract attention and monitoring from Head Office. These business units may find that they have a higher hurdle rate imposed on them than a company-wide cost of capital so that new product intensity also predicts an ABOVE outcome.

A second variable representing a possible strategic incentive is the occurrence of major new entry $(E N T)$. The results suggest that new entry favors the chance of a firm being in the 
EQUAL group and reduces the chance of a firm being in the ABOVE group. Entry appears to produce an aggressive response from companies that have previously had a conservative investment position.

The final set of discriminating variables concerns hypothesis $3(\mathrm{H} 3)$ - that non-diversified risk i.e. risk not accounted for in the discount rate - may influence hurdle rates via the role of an irreversibility constraint (Dixit and Pindyck 1994). Risk is measured by instability in the industry growth rate (INSTAB). This variable predicts against a BELOW outcome (at 10\%) and, also, for membership of the ABOVE group (significant at the $5 \%$ level). This provides some evidence that an additional influence from risk does bias hurdle rates upward. Figure 1 shows that its quantitative impact, while small, is not negligible.

\section{Summary and Conclusions}

In this paper we have looked at the relationship between hurdle rates and discount rates in order to understand the influence of a range of firm characteristics on investment appraisal. The first important finding is that there are a significant number of firms in our data which report hurdle rates below discount rates (the BELOW group which accounts for well over one fifth of the total sample). We argued that this may be explained by the presence of opportunities presented by strong cash flow and the absence of competitive market pressures, resulting in either agency costs which take the form of managerialist empire building or - as suggested by the real options literature - the pursuit of strategic objectives.

A second finding was that our data also contained a substantial number of observations where managers reported hurdle rates above the discount rate (the ABOVE group comprising roughly 
one fifth of the total). Here, the real options approach emphasizes the role played by irreversibility and uncertainty, generating a 'zone of inaction' for investment projects.

Given the theoretical background, our analysis focuses on: the opportunity for discretionary behaviour; the motivation or incentives to behave in a strategic fashion; as well as the risk of the business environment. These sets of influences are hypothesized to affect the likelihood that the hurdle rate will be greater than or less than the discount rate. The theoretical analysis suggests a multinomial logit analysis despite an apparent ordering of the groups, because some variables may have an asymmetric effect.

As both Table 2 and Figure 1 attest, the results are rather stronger in discriminating between the BELOW and EQUAL outcomes than between the ABOVE and EQUAL groups. Nevertheless, both sets of results give rise to interesting interpretations.

Focusing first on the variables that contribute most to distinguishing firms that adopt hurdles lower than the discount rate we identified a set of 'opportunity' variables, specifically cash flow and the environment for product market competition. These results (in Table 2) give support to the arguments in the literature that emphasize the tendency for managerially driven 'overinvestment' when strong market or other disciplines on management are absent. Though we have no direct variable for corporate governance, these results also support the view that the market environment (competitive pressure) substitutes for tight group oversight. However, as noted in the text, the significance of the opportunity variables is not a sufficient condition to identify behaviour. Managers may be using their freedom from short-term pressures to pursue strategic long-run aims (Stein 2003, p.131). To test this, we entered a number of other variables representing the incentive for strategic investment, in particular new product intensity. In the case of the first of these variables we again found a strong discriminating role, suggesting that 
managers are strategically focused when presented with greater autonomy. This is in keeping with much recent theoretical work on real follow-on options. High levels of risk also worked to discriminate against firms choosing hurdles less than the discount rate.

For the sample of firms with hurdles greater than their discount rate, the results suggest that rather different influences are at work. First there is the lack of significance for the opportunity variables other than cash flow - where the magnitude of the response is also small - so that increases in cash flow were estimated to have little effect on the probability of observing a member of the ABOVE group. The recent entry of a major competitor also appears to be important in lowering the probability of observing hurdle rates higher than the discount rate. This latter finding could plausibly be explained in terms of a competitive effect on businesses that had been holding back marginally profitable developments, providing some evidence of 'shirking'. which in our context is indistinguishable from managerial short-termism. Finally we also observe idiosyncratic risk to be important in explaining cautionary behaviour by this group.

The main message that emerges from this paper is that firms often use hurdle rates that are different from the cost of capital and that this observation needs to be taken seriously. Modeling capital investment without accounting for this is likely to result in poor estimates. Capital investment theory should be broadened to include the strategic incentives of managers and the extent of their discretion, both of which in turn are influenced by the institutional environment. 


\section{References:}

Abel, A.B and J.C. Eberly (1994) "A unified model of investment under uncertainty", American Economic Review 84, 1369-1384

Adler, R.W. (2006) "Why DCF capital budgeting is bad for business and why business schools should stop teaching it", Accounting Education 15(1) 3-10

Aggarwal, R. K. and A.A. Samwick (2006) "Empire-builders and shirkers: Investment , firm performance and managerial incentives", Journal of Corporate Finance 12, 489-515

Allen F. and D. Gale (2000) Comparing Financial Systems, Cambridge Mass. MIT Press

Antle R. and G.D. Eppen (1985) "Capital Rationing and Organizational Slack in Capital Budgeting", Management Science, 31(2), 163-174

Allen, F. and D. Gale (2000) "Governance and competition" in Vives X. (ed), Corporate Governance: Theoretical and Empirical Perspectives, Cambridge: Cambridge University Press

Baldenius, T. (2003) "Delegated investment decisions and private benefits of control", The Accounting Review 78(4), 909-930

Bar-llen, A. and W.C. Strange (1996) "Investment Lags", American Economic Review 86, 610-22

Baumol, W.J. (1958) "On the theory of oligopoly", Economica, 25, 187-198

Brealey, R. and S. Myers (2003) Principles of Corporate Finance, $7^{\text {th }}$ Edition McGraw Hill

Buzzell, R. and B.T. Gale (1987) The PIMS principles: linking strategy to performance, New York: The Free Press

Buzzell, R (2004) The PIMS program of strategy research: A retrospective appraisal Journal of Business Research, Volume 57(5) 478-483 
Caves, R. E. and P. Ghemawat (1992) "Identifying mobility barriers", Strategic Management Journal 13(1), 1-12

Chirinko, R.S. and H. Schaller (2002) "The irreversibility premium" paper given to the American Economic Association annual conference, Atlanta, January.

Clark, K. and Z. Griliches (1984), "Productivity and Growth at the Business Level: Results from the PIMS Data Base" in Z.Griliches (ed.) R\&D, Patents and Productivity, Chicago: Chicago University Press.

Dixit, A. and R. Pindyck (1994) Investment under uncertainty, Princeton: Princeton University Press

Driver, C, and D. Shepherd, (2005) "Capacity utilisation and corporate restructuring: a comparative study of the US, UK and other EU countries", CAMBRIDGE J ECON, Vol: 29, Pages: $119-140$

Driver, C. and B. Whelan (2001) "The effect of business risk on manufacturing investment: sectoral survey evidence from Ireland", Journal of Economic Behavior \& Organization, 44, 403412

Driver C, P. Temple P and G. Urga (2006) "Contrasts between classes of assets in fixed investment equations as a way of testing real option theory", Journal of Business and Economic Statistics, 24(4), 432-443.

Friedl, G. (2005) "Incentive properties of residual income when there is an option to wait", Schmalenbach Business Review, 57, 3-21

Folta, T.B. and J.P. O'Brien (2004) "Entry in the presence of dueling options", Strategic Management Journal 25, 121-138

Folta, T.B., D.R. Johnson and J.P. O'Brien (2004) “Uncertainty, irreversibility, and the likelihood of entry: an empirical assessment of the option to defer", Journal of Economic Behavior \& Organization, in press, online version available $17^{\text {th }}$ October. 
Geroski, P.A. (1995) "What do we know about entry?", International Journal of Industrial Organisation 13, 421-40

Ghemawat, P (1991) Commitment: the dynamic of strategy, New York, Free Press

Ghemawat, P. and R. E. Caves (1986) "Capital commitment and profitability - an empirical investigation", Oxford Economic Papers - new series 38:94-110 Supplement.

Ghosal, V. and P. Loungani (2000) "The Differential Impact of Uncertainty on Investment in Small and Large Businesses" . Review of Economics and Statistics, 82 (2), 338-343

Gillan, S. L. (2006) "Recent developments in Corporate Governance: an overview", Journal of Corporate Finance 12, 381-402

Greene, W.H. (2003) Econometric Analysis (5th edition), Upper saddle River, N.J. Prentice Hall/Pearson Education International

Grenadier S.R. and Neng Wang (2005) "Investment timing, agency and information", Journal of Financial Economics 75(3), 493-533

Grossman, S., and O. Hart (1982) "Corporate financial structure and managerial incentives", in J. McCall (ed.) The Economics of Information and Uncertainty, Chicaqo: Chicago University Press

Harris M. and A. Raviv (1996) "The Capital Budgeting Process: Incentives and Information", The Journal of Finance 51(4), 1139-1174

Hausman, J. and D. McFadden (1984) "A Specification Test for the Multinomial Logit Model" Econometrica, 52(5), 1219-1240

Hayes, R and D. Garvin (1982) "Managing as if Tomorrow Mattered", Harvard Business Review, May/June 71-79.

Henderson, J. and K. Cool (2003) "Corporate governance, investment bandwagons and overcapacity: an analysis of the worldwide petrochemical industry, 1975-95", Strategic Management Journal 24(4): 349-373 
Hennessy C.A. and A. Levy (2002) "A unified model of distorted investment: theory and evidence", Working Paper, Haas School of Business, U.C. Berkeley

Holmstrom, B. and J.R.I. Costa (1986) "Managerial Incentives and Capital Management" Quarterly Journal of Economics, 101(4); 835-860

Holmstrom, B. and S.N. Kaplan (2001) "Corporate Governance and Merger activity in the United States: Making sense of the 1980s and 1990s", The Journal of Economic Perspectives 15(2): 121-144

Hubbard, R.G. (1998) "Capital market imperfections and investment”, Journal of Economic Literature, March, 193-225.

Jagannathan, R. and I. Meier (2002) "Do we need CAPM for capital budgeting?" National Bureau of Economic Research working paper \#8719, Cambridge Mass.

Jensen, M.C. (1986) "Agency costs of free cash flow, corporate finance and take-overs" American Economic Review, 76, 323-329

Jensen, M. (1993)"The modern industrial revolution, exit and the failure of internal control systems", Journal of Finance 48;3, 831-880

Kaplan. R. S. (1986) "Must CIM be justified by faith alone", Harvard Business Review, 64(2) 8795

Kathuria, R. and D.C. Mueller (1995) "Investment and cash flow: asymmetric information or managerial discretion" Empirica, 22: 211-234.

Kulatilaka, N. and E.C. Perotti (1998), "Strategic growth options," Management Science, 44(8), 1021-1031

Long, J. Scott, and J. Freese (2003) Regression Models for Categorical Dependent Variables Using STATA, 2nd ed. College Station, TX: STATA Press 
McDonald, R.L. (2000) "Real Options and Rules of Thumb in Capital Budgeting" in M. J. Brennan and L. Trigeorgis (eds.), Project Flexibility, Agency, and Competition, London: Oxford University Press

Marris, R.L. (1964) “The Economic Theory of 'Managerial” Capitalism” London: Macmillan 1964

Miller, K.D. and T.B. Folta (2002) "Option value and entry timing", Strategic Management Journal 23(7), 655-665

National Research Council (1994) "Investing for productivity and prosperity", Board on Science , Technology and Economic Policy, Washington DC: National Academic Press

Nickell, S.J. (1996) Competition and Corporate Performance, Journal of Political Economy, 104(4), 724-746

Odagiri, H. (1981) Theory of growth in a corporate economy: management preference, research and development and economic growth, Cambridge: Cambridge University Press.

Odagiri, H. (1992) Growth through competition, competition through growth: Oxford: Oxford University Press

Opler, T.C. and S. Titman (1994) "Financial distress and corporate performance", Journal of Finance 49, 1015-1040

Pawlina, G. and P.M. Kort (2006) "Real Options in an Asymmetric Duopoly:

Who Benefits from Your Competitive Disadvantage?" Journal of Economics \& Management Strategy, 15(1), 1-35

Poterba, M. and L.H.Summers (1995) "A CEO Survey of Companies' Time Horizons and Hurdle Rates," Sloan Management Review, 37(1), 43-53

Qi Chen and Wei Jiang (2004) "Positive hurdle rates without asymmetric information", Finance Research Letters (2004) 106-112

Roberts, K (2003) "What strategic investments should you make during a recession to gain competitive advantage in the recovery? "Strategy \& Leadership 31 (4), 31 - 39 
Romer, D (2000) Advanced Macroeconomics, New York, McGraw Hill

Schwartz, E.S. and L. Trigeorgis (2001) Real Options and Investment under Uncertainty: Classical Readings and Recent Contributions, Cambridge Mass: MIT Press

Small, K.A. and C. Hsiao (1985) "Multinomial Logit Specification Tests," International Economic Review, 26, 619-627

Stein, J, (2003) "Agency, information and corporate investment" In Handbook of the Economics of Finance, Edited by George Constantinides, Milton Harris and Rene Stulz, Elsevier Science B.V

Stulz R.M. (1999) "What's wrong with modern capital budgeting" Address to the Easter Finance Association, April

Taggart, R.A. Jr., (1987) "Allocating Capital Among a Firm's Divisions: Hurdle Rates vs. Budgets," Journal of Financial Research, 10 (3), 177-189

Wambach A (2000) "Payback criterion, hurdle rates and the gain of waiting", International Review of Financial Analysis 9, 247-258

Wulf, J. (2002) Internal Capital Markets and Firm-Level Compensation Incentives for Division Managers, Journal of Labor Economics, 20 (2002), pages S219-S262 


\section{DATA AND RESULTS APPENDIX}

\section{Variables and \\ Descriptions}

\begin{tabular}{|c|c|}
\hline Variable & |Identifier \\
\hline Cash-flow sales rank & $L I Q$ \\
\hline $\begin{array}{l}\text { Cash-flow sales } \\
\text { squared/10000 }\end{array}$ & LIQSQ \\
\hline $\begin{array}{l}\% \text { sales channelled } \\
\text { to distribution facility }\end{array}$ & SDF \\
\hline $\begin{array}{l}\% \text { sales channelled } \\
\text { to retailer }\end{array}$ & $S R$ \\
\hline Capacity quantum & LUMP \\
\hline $\begin{array}{l}\text { Ratio of fixed capital } \\
\text { to sales }\end{array}$ & $K S$ \\
\hline $\begin{array}{l}\% \text { sales from new } \\
\text { products }\end{array}$ & SNP \\
\hline Major entry & ENT \\
\hline Industry instability & INSTAB \\
\hline Discount rate & $D R$ \\
\hline Hurdle rate & HS \\
\hline $\begin{array}{l}\text { Proprietary } \\
\text { Processes }\end{array}$ & PROP \\
\hline
\end{tabular}

\section{Description}

Free cash flow expressed as a ratio of sales and ranked inversely (1=lowest)

As above, squared

$\%$ of sales made to company-owned distribution facilities

$\%$ of sales made to retailers

This is defined in the survey as the "minimum economically efficient amount" by which the standard capacity of the business could be increased, expressed as a percentage of the previous years capacity.

Gross book value of plant and equipment as a percentage of sales

Percentage of sales accounted for by products introduced in the last five years

Entry is major if it accounts for $5 \%$ of sales and has taken place within 3 years

RMSE index of industry sales instability over five years

See definition in text

See definition in text

Dummy $=1$ if process is protected to a significant degree by patent, trade secrets or other proprietary methods 


\section{TABLE A1}

Correlation Matrix for Variables Used -

Total Sample

\begin{tabular}{|c|c|c|c|c|c|c|c|c|c|c|c|c|}
\hline & $L I Q$ & LIQSQ & $S D F$ & $S R$ & LUMP & $K S$ & SNP & $E N T$ & MSR & INSTAB & $D R$ & $H R$ \\
\hline Cash-flow sales ( $L I Q)$ & 1.000 & & & & & & & & & & & \\
\hline Cash-flow sales squared ( $L I Q S Q$ ) & 0.969 & 1.000 & & & & & & & & & & \\
\hline $\begin{array}{l}\% \text { sales channelled to distribution } \\
\text { facility (SDF) }\end{array}$ & -0.012 & -0.010 & 1.000 & & & & & & & & & \\
\hline$\%$ sales channelled to retailer ( $\boldsymbol{S} \boldsymbol{R}$ ) & -0.052 & -0.068 & -0.030 & 1.000 & & & & & & & & \\
\hline Capacity quantum ( LUMP) & -0.035 & -0.019 & 0.013 & -0.043 & 1.000 & & & & & & & \\
\hline Ratio of fixed capital to sales (KS) & -0.127 & -0.081 & -0.034 & -0.126 & 0.067 & 1.000 & & & & & & \\
\hline$\%$ sales from new products (SNP) & -0.181 & -0.147 & 0.040 & 0.012 & 0.058 & -0.091 & 1.000 & & & & & \\
\hline Major entry ( $E N T$ ) & 0.012 & 0.029 & 0.009 & -0.060 & 0.024 & -0.037 & 0.098 & 1.000 & & & & \\
\hline Industry instability (INSTAB) & 0.041 & 0.043 & -0.023 & 0.000 & -0.012 & 0.019 & 0.024 & 0.001 & 0.019 & 1.000 & & \\
\hline Discount rate $(\boldsymbol{D} \boldsymbol{R})$ & 0.043 & 0.045 & -0.018 & -0.012 & 0.057 & -0.022 & -0.020 & -0.007 & -0.059 & -0.045 & 1.000 & \\
\hline Hurdle Rate ( $\boldsymbol{H} \boldsymbol{R})$ & -0.030 & -0.019 & -0.029 & 0.035 & -0.004 & -0.071 & -0.001 & 0.012 & -0.035 & 0.025 & 0.474 & 1.000 \\
\hline
\end{tabular}




\section{TABLE A2}

\section{SUMMARY STATISTICS}

\section{Total Sample}

Variable

Cash-flow sales ( $L I Q)$

Cash-flow sales squared ( LIQSQ)

$\%$ sales channelled to distribution

facility (SDF)

\% sales channelled to retailer ( $\boldsymbol{S} \boldsymbol{R}$ )

Capacity quantum ( LUMP)

Ratio of fixed capital to sales (KS)

$\%$ sales from new products ( SNP )

Major entry (ENT)

Market share rank (MSR)

Industry instability (INSTAB)

Discount rate $(\boldsymbol{D R})$

Hurdle Rate ( $\boldsymbol{H} \boldsymbol{R})$

\section{SAMPLE $=$ BELOW}

Variable

Cash-flow sales ( $L I Q)$

Cash-flow sales squared ( $L$ IQSQ)

$\%$ sales channelled to distribution facility (SDF)

\% sales channelled to retailer ( $\boldsymbol{S} \boldsymbol{R}$ )

Capacity quantum ( $L U M P$ )

Ratio of fixed capital to sales (KS)

\% sales from new products ( SNP)

Major entry ( $E N T$ )

Industry instability (INSTAB)

Discount rate $(\boldsymbol{D R})$

Hurdle Rate ( $\boldsymbol{H} \boldsymbol{R})$
Obs

Mean

Std. Dev.

Min

$\operatorname{Max}$

2382

50.0

28.9

0.1

100.0

2382

3335.4

2983.2

0.0

10000.0

2377

4.6

15.2

0.0

100.0

2377

18.5

32.2

0.0

100.0

2308

17.5

21.6

0.0

100.0

2382

45.2

32.8

3.0

170.0

2351

7.8

15.2

0.0

99.0

2368

0.3

0.4

0.0

1.0

2382

2.6

2.1

1.0

10.0

1578

11.4

9.6

0.0

40.0

2382

11.7

3.0

2.0

20.0

2382

11.5

3.0

4.0

20.0

Obs

Mean

Std. Dev.

Min

Max

505

52.3

27.4

0.6

99.7

505

3481.

2890.4

0.4

9949.7

504

$$
6.1
$$

17.7

0.0

100.0

504

14.4

27.9

0.0

100.0

499

19.3

22.0

0.0

100.0

505

47.2

32.7

3.0

170.0

502

8.5

16.5

0.0

90.8

504

0.2

0.4

0.0

1.0

374

10.5

8.7

0.0

40.0

505

14.0

2.7

8.0

20.0

505 


\section{SAMPLE=EQUAL}

\section{Variable}

Cash-flow sales ( $L I Q)$

Cash-flow sales squared ( LIQSQ)

$\%$ sales channelled to distribution

facility (SDF)

\% sales channelled to retailer ( $\boldsymbol{S} \boldsymbol{R}$ )

Capacity quantum ( LUMP)

Ratio of fixed capital to sales (KS)

$\%$ sales from new products ( SNP)

Major entry (ENT)

Industry instability (INSTAB)

Discount rate ( $\boldsymbol{D} \boldsymbol{R})$

Hurdle Rate ( $\boldsymbol{H} \boldsymbol{R})$
Obs Mean Std. Dev. Min Max

$\begin{array}{rrrrr}1425.0 & 50.0 & 29.0 & 0.1 & 100.0 \\ 1425.0 & 3343.7 & 3006.0 & 0.0 & 10000.0 \\ 1423.0 & 3.9 & 13.8 & 0.0 & 100.0 \\ 1423.0 & 19.8 & 33.5 & 0.0 & 100.0 \\ 1379.0 & 16.7 & 21.8 & 0.0 & 100.0 \\ 1425.0 & 44.2 & 32.4 & 3.0 & 170.0 \\ 1403.0 & 6.5 & 12.9 & 0.0 & 99.0 \\ 1418.0 & 0.3 & 0.4 & 0.0 & 1.0 \\ 893.0 & 11.5 & 9.7 & 0.0 & 40.0 \\ 1425.0 & 11.4 & 2.7 & 6.0 & 20.0 \\ 1425.0 & 11.4 & 2.7 & 6.0 & 20.0\end{array}$

Obs

Mean Std. Dev.

Min Max

VAMPLE

Cash-flow sales ( $L I Q)$

Cash-flow sales squared ( $L I Q S Q$ )

$\%$ sales channelled to distribution

facility $(S D F)$

\% sales channelled to retailer ( $\boldsymbol{S} \boldsymbol{R})$

Capacity quantum ( $L$ UMP

Ratio of fixed capital to sales (KS)

$\%$ sales from new products ( SNP)

Major entry ( $E N T)$

Market share rank ( $M S R$ )

Industry instability (INSTAB)

Discount rate (DR)

Hurdle Rate ( $\boldsymbol{H} \boldsymbol{R})$
452

452

450

450

430

452

446

446

452

311

452

452

Mean

52

$$
47.5
$$$$
3146.8
$$

29.9

3009.6

$$
5.1
$$

19.2

16.5

32.1

17.7

20.3

46.0

34.2

19.2

10.9

0.2

2.7

12.2

10.0

13.3

$$
0.4
$$$$
2.2
$$

10.4

2.7

3.6
99.9

9974.9

100.0

100.0

100.0

170.0

99.0

1.0

10.0

40.0

18.0

20.0 


\section{TABLE A3}

\section{Additional Statistics for result sets $\mathbf{1 . 1}$ and $\mathbf{1 . 2}$}

Result Set (see table 1)

$1.1 \quad 1.2$

McFaddens adjusted $R^{2}$

$0.013 \quad 0.017$

Cragg and Uhler's $\mathrm{R}^{2}$

$0.049 \quad 0.059$

Adjusted Count $\mathrm{R}^{2}$

$0.011 \quad 0.005$

LR test of 1.1 against 1.2

$\mathrm{P}>\mathrm{Chi}^{2}$

0.000

Hausman Test of IIA ssumption

$\mathrm{HO}$ : odds of pairs of outcome are independent of other alternatives

omitted outcome

BELOW

ABOVE

Small-Hsiao tests of IIA assumption

$\mathrm{HO}$ : odds of pairs of outcome are independent of other alternatives

omitted outcome:

BELOW

0.500

0.085

ABOVE

0.177

0.229 
TABLE 1

Results from Multinomial Logit Estimation

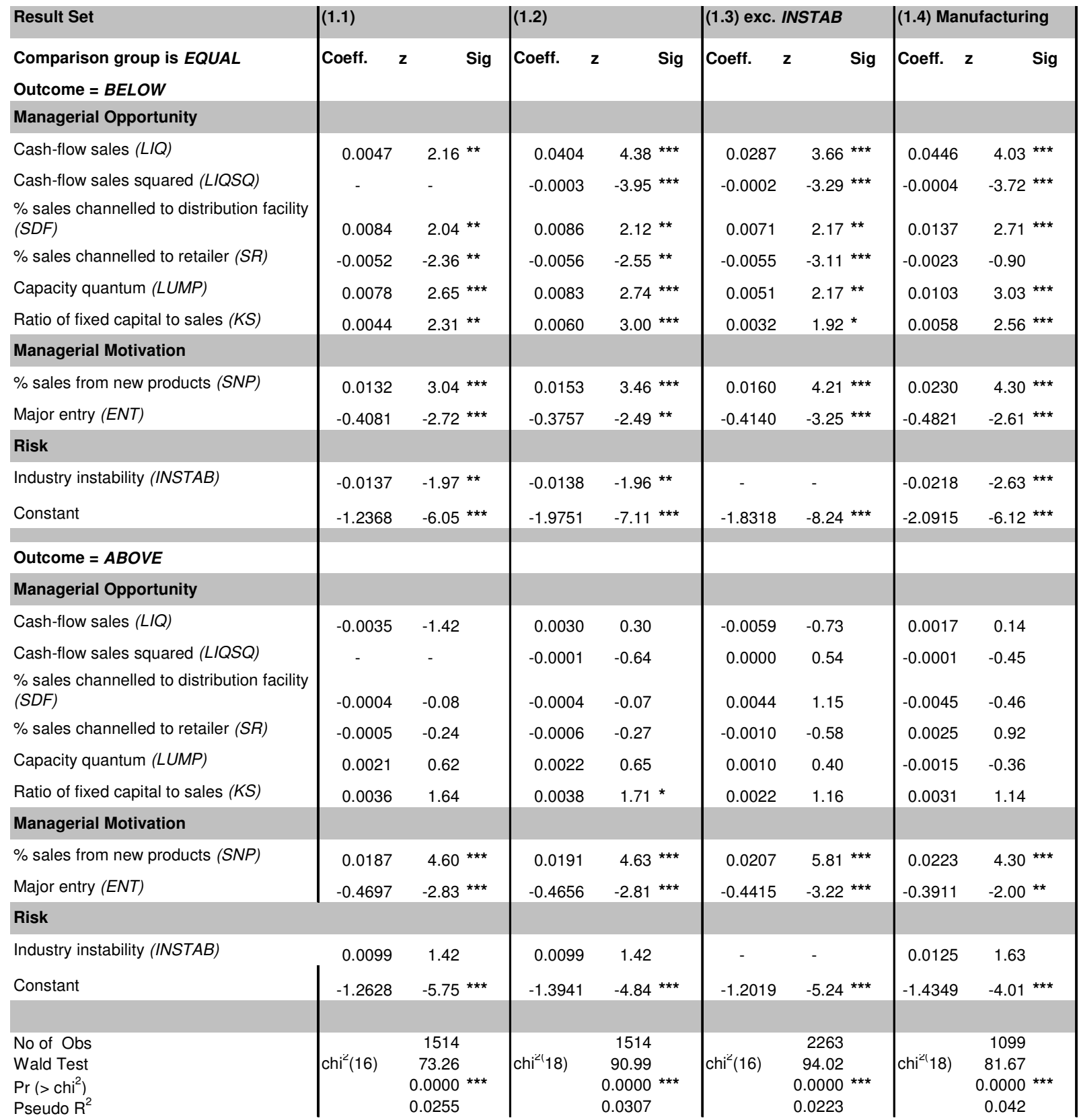

* = significant at $10 \%$

** = significant at $5 \%$

${ }^{\star \star *}=$ significant at $1 \%$ 
TABLE 2

Marginal Probabilities:

The impact on probabilities for each outcome of a unit change in the stated variable

Based on Table 1 result set 1.2

\section{BELOW OUTCOME}

marginal

evaluated at: probability

\section{EQUAL OUTCOME}

marginal

z sig evaluated at: probability

\section{ABOVE OUTCOME}

marginal

evaluated at: probability

z sig

\begin{tabular}{|c|c|c|c|c|c|c|c|c|c|}
\hline \multicolumn{10}{|l|}{ Managerial Opportunity } \\
\hline Cash-flow sales (LIQ) & mean & 0.0084 & $4.01^{\star \star \star}$ & mean & -0.0064 & $-3.31^{\star \star *}$ & mean & -0.0020 & -1.39 \\
\hline Cash-flow sales squared (LIQSQ) & - & -0.0001 & $-3.54^{\star \star \star}$ & - & 0.0001 & $3.16^{\star \star \star}$ & - & 0.0000 & 0.79 \\
\hline $\begin{array}{l}\text { \% sales channelled to distribution facility } \\
\text { (SDF) }\end{array}$ & mean & 0.0019 & 2.24 ** & mean & -0.0013 & -1.33 & mean & -0.0006 & -0.69 \\
\hline$\%$ sales channelled to retailer (SR) & mean & -0.0012 & $-2.54^{\star \star}$ & mean & 0.0009 & $2.07^{\star *}$ & mean & 0.0002 & 0.73 \\
\hline Capacity quantum (LUMP) & mean & 0.0016 & $2.72 * \star \star$ & mean & -0.0015 & $-2.25 * \star$ & mean & -0.0002 & -0.31 \\
\hline Ratio of fixed capital to sales (KS) & mean & 0.0010 & $2.51 * \star$ & mean & -0.0013 & $-3.06^{\star \star *}$ & mean & 0.0002 & 0.72 \\
\hline \multicolumn{10}{|l|}{ Managerial Motivation } \\
\hline$\%$ sales from new products (SNP) & mean & 0.0021 & $2.40^{\star \star}$ & mean & -0.0042 & $-4.54^{\star \star \star}$ & mean & 0.0021 & $3.38^{* * \star}$ \\
\hline Major entry (ENT) & 0 & -0.0531 & $-1.87^{\star}$ & 0 & 0.1012 & $3.32^{\star \star \star}$ & 0 & -0.0482 & $-2.21^{\star *}$ \\
\hline \multicolumn{10}{|l|}{ Risk } \\
\hline Industry instability (INSTAB) & mean & -0.0035 & $-2.47^{\star \star}$ & mean & 0.0011 & 0.80 & mean & 0.0024 & $2.12^{\star \star}$ \\
\hline
\end{tabular}

${ }^{*}=$ significant at $10 \%$

${ }^{\star *}=$ significant at $5 \%$ 
FIGURES

Figure 1

Comparative Impact on Probabilities of a Unit Change in Variables

(Multiplied by standard deviation)

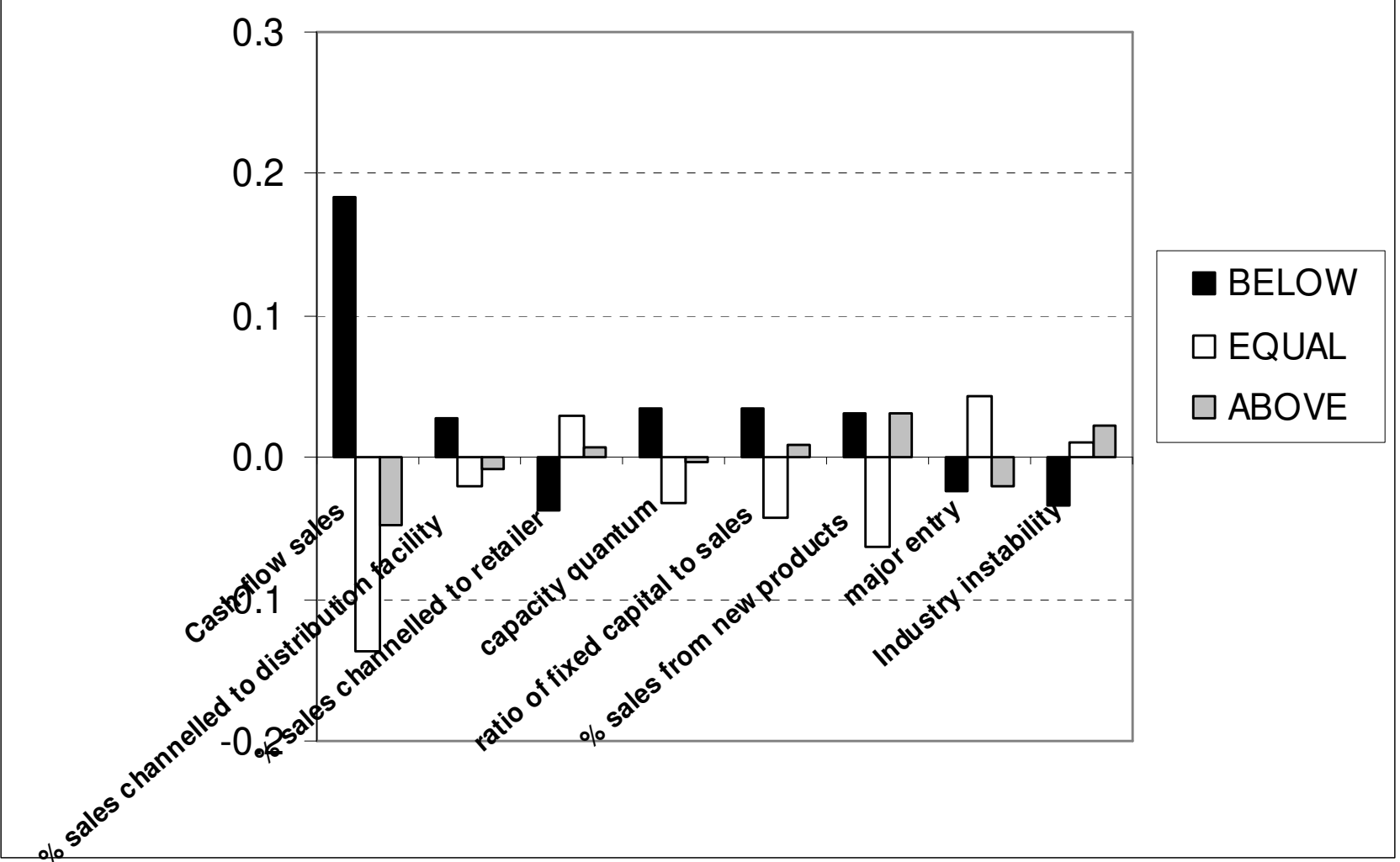




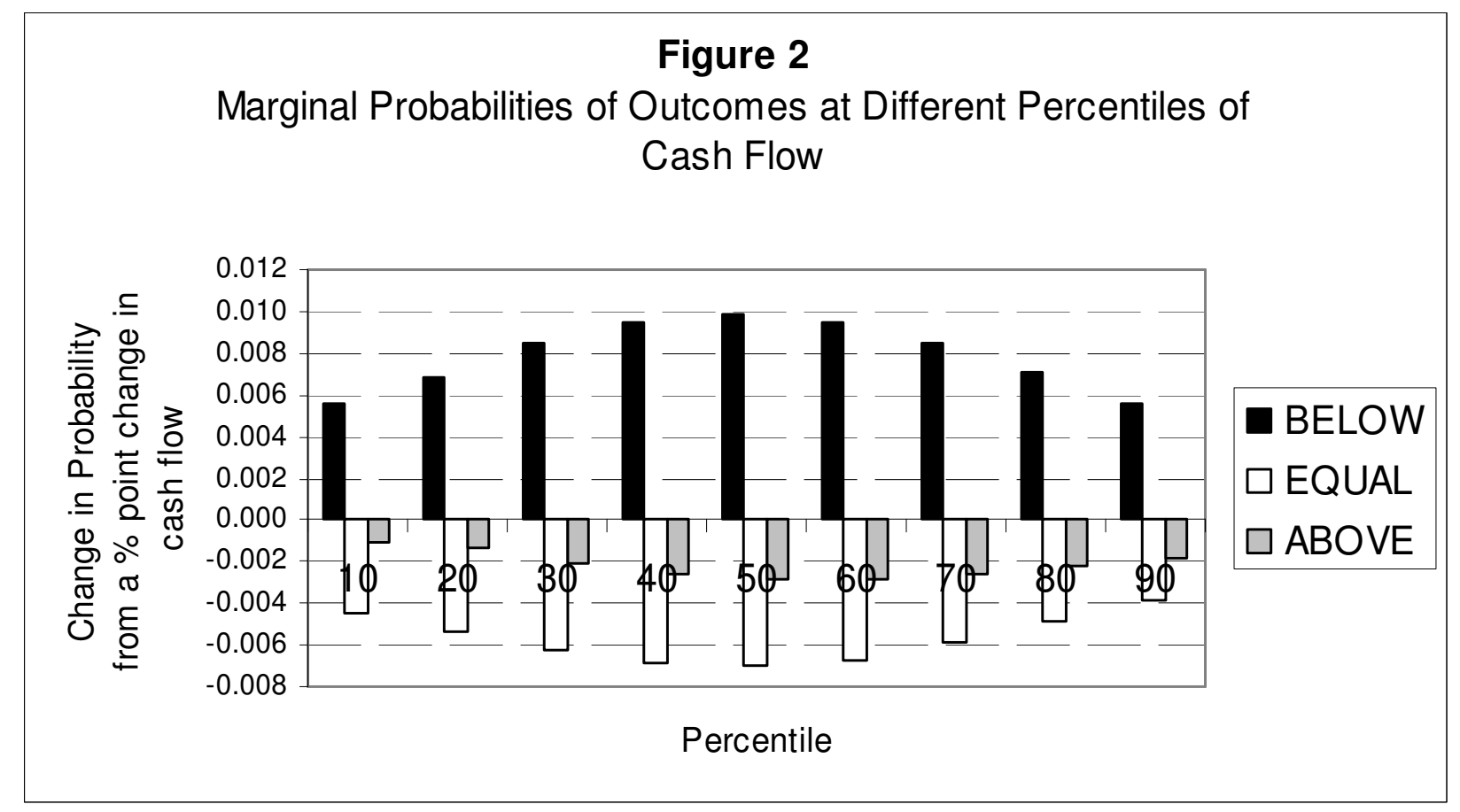

